\title{
Review \\ Effect of Wettability and Uniform Distribution of Reinforcement Particle on Mechanical Property (Tensile) in Aluminum Metal Matrix Composite-A Review
}

\author{
Johny James ${ }^{1,+} \mathbb{D}$, A. Raja Annamalai ${ }^{2,+}+\mathbb{C}$, A. Muthuchamy ${ }^{3}$ and Chun-Ping Jen ${ }^{4,5, *} \mathbb{C}$ \\ 1 Department of Mechanical Engineering, Sri Venkateswara College of Engineering \& Technology, \\ Chittoor 517127, India; johnyjames2002@yahoo.com \\ 2 Centre for Innovative Manufacturing Research, Vellore Institute of Technology, Vellore 632014, India; \\ raja.annamalai@vit.ac.in \\ 3 Department of Metallurgical and Materials Engineering, National Institute of Technology, \\ Tiruchirappalli 620015, Tamil Nadu, India; muthuchamy@nitt.edu \\ 4 School of Dentistry, College of Dental Medicine, Kaohsiung Medical University, Kaohsiung 80708, Taiwan \\ 5 Department of Mechanical Engineering and Advanced Institute of Manufacturing for High-Tech Innovations, \\ National Chung Cheng University, Chia-Yi 62102, Taiwan \\ * Correspondence: chunpingjen@alum.ccu.edu.tw \\ + These authors contributed equally to this work.
}

check for

updates

Citation: James, J.; Annamalai, A.R.; Muthuchamy, A.; Jen, C.-P. Effect of Wettability and Uniform Distribution of Reinforcement Particle on Mechanical Property (Tensile) in Aluminum Metal Matrix Composite-A Review. Nanomaterials 2021, 11, 2230. https://doi.org/ $10.3390 /$ nano11092230

Academic Editor: Zhanxi Fan

Received: 30 July 2021

Accepted: 26 August 2021

Published: 29 August 2021

Publisher's Note: MDPI stays neutral with regard to jurisdictional claims in published maps and institutional affiliations.

Copyright: (C) 2021 by the authors Licensee MDPI, Basel, Switzerland. This article is an open access article distributed under the terms and conditions of the Creative Commons Attribution (CC BY) license (https:// creativecommons.org/licenses/by/ $4.0 /)$.

\begin{abstract}
There is a massive demand for low-weight high strength materials in automotive, space aerospace, and even structural industries in this present engineering world. These industries attract composites only because of their high strength, resistance to wear, and low weight. Among these composites, metal matrix composite finds wide applications due to its elevated properties, excellent resistance property, corrosion resistance, etc. The reinforcements exist in particles, fiber, and whiskers. Among the three, particles play an important role because of their availability and wettability with the metal matrix. Additionally, among the various metal matrices such as aluminum, magnesium, copper, titanium, etc., aluminum plays a vital role among metal matrices because of its cost, availability in abundance, and castability. Stir casting is the most inexpensive and straightforward composite fabrication technique among the prevailing techniques. Even though so many factors contribute to the elevated property of composites, metal matrix, and reinforcement phase, uniform distribution and wettability are essential factors among all the other factors. This review aims to develop a composite with elevated property in a cost-effective manner. Cost includes metal matrix, reinforcement, and processing technique. Various works have been tabulated to achieve the above objective, and analysis was carried out on tensile strength concerning microstructure. This review paper explores the challenges in composite fabrication and finds a solution to overcome them.
\end{abstract}

Keywords: aluminum; composite; microstructure; mechanical properties; porosity

\section{Introduction}

Technological innovation, the higher speed with less fuel consumption, the need for elevated property, and costs are the motivations for inventing newer materials. For the aerospace and automotive industry, weight reduction is an essential requirement that paves the way for new reinforcements and metal matrix to develop metal matrix composite. Indeed, composites are not new but have existed for many centuries. Old Testament records the use of straw in the fabrication of brick before 5500 years. Notwithstanding, the bulk production of composites was before three decades only. Composites are a combination of mainly two main constituents, i.e., metal matrix phase and reinforcement phase. Judicial selection of the reinforcement type, particle size, and metal matrix phase and fabrication technique results in the elevated property [1]. 


\subsection{Category of Composites}

Composites are generally categorized into three main categories based on the matrix substance. They are called metal matrix composite (MMC), polymer matrix composite (PMC), and ceramic matrix composite (CMC), respectively [2]. MMC gives more elevated ductile properties than CMCs and better environmental stability than PMCs. Additionally, MMCs offer good thermal conductivity (from 220 to $580 \mathrm{~W} \cdot \mathrm{m}^{-1} \cdot \mathrm{K}^{-1}$ ), wear resistance (0.01025), wear rate $\left(\mathrm{g} \cdot \mathrm{m}^{-1}\right)$, erosion, and shear strength [3-10].

\subsection{Matrix Materials in MMCs}

Since the day work on metal matrix composites commenced, aluminum and its alloys played a vital role as matrix materials due to the increase in demand for high-strength, lightweight components. Similarly, magnesium and titanium alloys are also employed as metal matrix material, but both have their demerits because magnesium quickly reacts with the atmosphere, so processing is complicated; as for titanium, it is highly reactive and forms inter-metallics with many reinforcement materials [11,12].

\subsection{Reinforcements}

Suitable reinforcing material needs to be chosen to fit a given material. The standard form of reinforcements is particles, whiskers, and fibers (continuous or discontinuous). The particles develop the property of the composite by dispersion strengthening and by hindering the movement of dislocations. Additionally, when reinforcing materials are added as particles, they impart isotropic properties. The commonly employed reinforcements are $\mathrm{SiC}, \mathrm{Al}_{2} \mathrm{O}_{3}, \mathrm{TiB}_{2}$, and $\mathrm{B}_{4} \mathrm{C}$, etc.

\subsection{Applications of MMCs}

Based on the statistics, most aircraft components have been replaced by composites, and a considerable amount are MMCs. Additionally, many automotive engine manufacturers already replaced forged steel with MMCs. Piston, piston ring, connecting rod, brake rotor, cylinder liner bearings, bushings, etc., are some of the components made by MMCs due to their wear resistance, high strength, specific stiffness, and fatigue strength $[13,14]$.

\subsection{Production of MMCs}

Various processing techniques are employed in the fabrication of MMCs. They are powder metallurgy, diffusion bonding, spray co-deposition, and casting routes. The casting route is one of the most common and economical from the above fabrication techniques even though it has limitations like porosity and agglomeration defects. Stir casting is commonly acknowledged as a proven technique, presently adopted commercially as well. In addition, stir casting permits a conventional metal processing technique to be integrated or replaced; this leads to cost reduction [15]. Furthermore, this liquid casting method is a low cost compared to the other entire composite fabrication method [16] and permits huge dimensional components.

Skibo, $\mathrm{M}$ reported that the price of producing composites using a casting route is almost $1 / 3$ to $1 / 2$ of other existing routes, but for colossal size production, it may even fall to $1 / 10$ of the cost by other methods. Even though it has few limitations, they can be overcome by using stir casing integrated with a squeeze casing unit $[17,18]$.

\subsection{Various Metal Matrix and Reinforcement Phases of Advanced Composites Using Different Techniques}

H. Abdizadeh processed composite using A356 aluminum alloy and $\mathrm{ZrO}_{2}$ by stir casting method. The vol.\% of reinforcement varies from 5 to 15 percent, and the temperatures were 750,850 , and $950{ }^{\circ} \mathrm{C}$, respectively. It was reported that aluminum alloy reinforced with $\mathrm{ZrO}_{2}$ particles enhanced UTS and hardness compared to A356 aluminum alloy, and its maximum values were $232 \mathrm{MPa}$ and $70 \mathrm{BHN}$, respectively. For 15 vol.\% of $\mathrm{ZrO}_{2}$ composition, the highest UTS, and hardness values were obtained [19]. 
Baghchesara, M. A produced composite using A356 aluminum alloy and $\mathrm{ZrO}_{2}$ by stir casting method. Various samples of 5, 10, and 15 volume percent of $\mathrm{ZrO}_{2}$ in different casting temperatures of 750,850 , and $950{ }^{\circ} \mathrm{C}$ were prepared. The maximum tensile strength was recorded in the sample having 15 vol. $\% \mathrm{ZrO}_{2}$ prepared at $750{ }^{\circ} \mathrm{C}$, which shows an enhancement of $60 \%$ compared to the aluminium-356 parent alloy. Additionally, it has been concluded that the composite fracture was severely brittle by increasing $\mathrm{ZrO}_{2}$ particle quantity and casting temperature [20].

M. Hajizamani fabricated composite using $\mathrm{A} 356$ and $\mathrm{ZrO}_{2}$ by stir casting method. In this work, nanoparticles of $\mathrm{ZrO}_{2}$ and $\mathrm{Al}_{2} \mathrm{O}_{3}$ were constituted to produce composites with a composition of $0.5-2 \mathrm{wt} . \%$ of the reinforcement. This work records that by raising the reinforcement, density reduced while yield, ultimate tensile strength (UTS), and compressive strength improved. The ductility of the composite specimens was low due to high porosity and the formation of voids. Additionally, hardness improved at one weight percent of $\mathrm{Al}_{2} \mathrm{O}_{3}$ and 10 weight percent of $\mathrm{ZrO}_{2}$. However, for the hardness of the specimen at 1.5-2 weight percent of $\mathrm{Al}_{2} \mathrm{O}_{3}$ and 10 weight percent $\mathrm{ZrO}_{2}$ again the hardness value came down [21].

G.Karthikeyan selected aluminum LM25 as the parent material, reinforced with 0-15\% of zirconium oxide prepared by stir casting route. Wear and tensile specimens were made per ASTM G99 and ASTM B-557-M-94 standard. A surface roughness test was done on wear specimens. The test shows that a rise in $\mathrm{ZrO}_{2}$ particles percentage promotes surface roughness value [22].

Using the stir casting method, S. Prajval prepared a metal matrix composite by combining aluminum $\mathrm{A} 356$ and titanium dioxide $(\mathrm{TiO} 2)$ with various mica percentages $(1 \%$, $2 \%, 3 \%, 4 \%$, and $5 \%$ ). It has been concluded that the UTS value is highly influenced by the percentage of mica and $\mathrm{TiO}_{2}$ present in the composite. Additionally, the UTS value is noteworthily influenced by the process of heat treatment and aging method. The hardness of the specimens increases when the reinforcement in the composite specimen increases [23].

T. Rajmohan studied the property of hybrid A356 metal matrix composite reinforced with mica and SiC particles. Micrographs were investigated with the help of SEM. EDX was used to study the material composition. The results showed that better hardness was obtained for the composition of $10 \mathrm{wt} . \%$ of $\mathrm{SiC}$ and $3 \mathrm{wt} . \%$ of mica. The rise in weight percent of mica enhances the wear-resistant property of the composite [24].

R. Raj processed 6061Al- $\mathrm{B}_{4} \mathrm{C}$, the composite containing different wt.\% of $\mathrm{B}_{4} \mathrm{C}$ using advanced stir casting method with bottom pouring set-up. The dispersion of particles of $\mathrm{B}_{4} \mathrm{C}$ in the aluminum matrix, interfacial characteristics, and microstructural features was qualitatively studied using an optical microscope and field emission scanning electron microscope (FESEM). Microstructural characterization revealed that the distribution of $\mathrm{B}_{4} \mathrm{C}$ in the metal matrix phase was comparatively uniform, and at some locations, small-scale agglomeration and clustering of particles were observed. Particle size distribution has been studied for the quantitative description of agglomeration of $\mathrm{B}_{4} \mathrm{C}$ particles, revealing small-scale agglomeration of particles. Homogeneity and randomness of $\mathrm{B}_{4} \mathrm{C}$ particulates across the matrix phase have been calculated by the quadrant method. The results show a random spatial distribution of particles with small-scale clustering [25].

B. P Beyrami fabricated composite using A356 and $\mathrm{ZrO}_{2}$ nanoparticles. Samples of composites were made at different percentages of $\mathrm{ZrO}_{2}(1.5,2.5$, and $5 \mathrm{vol} . \%)$. The casting temperatures were selected as $800-950{ }^{\circ} \mathrm{C}$. Micrographs of composite samples were studied using scanning electron microscopy (SEM) and energy dispersive X-ray spectroscopy (EDS). Mechanical properties such as compressive yield strength, toughness, and hardness were calculated. The experimental results depict that mechanical properties like compressive yield strength and hardness are noticeably picked up by adding $\mathrm{ZrO}_{2}$ particles. The highest values were for samples containing $2.5 \mathrm{vol} . \%$ of particles fabricated at $850{ }^{\circ} \mathrm{C}$ [26].

Two sets of cast composite specimens were prepared by stir casting fixing the $10 \%$ of fly ash and varying ( $5 \%$ and $10 \%)$ zirconia by weight fraction. S. Malhotra et al. reported that the optimum casting conditions of the composite fabrication were attained with 
$10 \mathrm{wt} . \% \mathrm{ZrO}_{2}$ and $10 \mathrm{wt} . \%$ fly ash. There is a considerable increase in tensile, elongation, and hardness value [27]. M. Ramachandra synthesized composite using $\mathrm{Al} 6061$ and $\mathrm{ZrO}_{2}$ to study corrosion behavior by the stir casting process. This work reports that the corrosion rate of the parent material is higher than the cast composite, and the best property is achieved in $7.5 \mathrm{wt} . \% \mathrm{ZrO}_{2}$ specimen [28].

D. M. Patoliya prepared composite using $\mathrm{Al} 6061$ and $\mathrm{ZrO}_{2}$ by the stir casting process. Four specimens were prepared to vary wt.\% from 0 to 7.5 , keeping all other parameters the same. It is also reported that tensile strength, hardness, and impact strength have been promoted parallel to the rise in weight fraction of zirconium oxide particles in the $\mathrm{Al} 6061$ matrix, but elongation decreased with increase in wt percent of $\mathrm{ZrO}_{2}$ in the $\mathrm{Al}$ 6061 matrix [29].

P. R Thyla fabricated composite using $\mathrm{Al} 6061, \mathrm{Gr}, \mathrm{SiC}$, and $\mathrm{ZrO}_{2}$ by the stir casting process. Five different samples were prepared to study the corrosion behavior. It has been reported that the corrosion rate decreased due to the presence of ceramic particles in the matrix material. Specifically, $9 \%$ wt percent sample records a very minimum corrosion rate [30].

The above works of various researchers show the development of composites using aluminum alloy and various reinforcements with different particle sizes and compositions. It proves the successful development of composite. One of the main objectives of composite is to achieve high strength. Table 1 gives a detailed report of the metal matrix, reinforcement, and the tensile strength achieved.

Table 1. Various tensile strength values of developed composites.

\begin{tabular}{|c|c|c|c|c|c|}
\hline S.L. No & Author & Metal Matrix & $\%$ and Reinforcement & Tensile Strength in MPa & Reference \\
\hline 1 & Kalaiselvan (2011) & AA6061 & 12 wt. $\% \mathrm{~B}_{4} \mathrm{C}$ & 215 & {$[31]$} \\
\hline 2 & Amirkhanlou and Niroumand (2011) & A356 & 5 vol. $\%$ SiC & 89 & [32] \\
\hline 3 & Alizadeh (2011) & $\mathrm{Al}$ & 2 wt. $\% \mathrm{~B}_{4} \mathrm{C}$ & 197 & [33] \\
\hline 4 & Kumar (2012) & AA6061 & 20 wt. $\%$ AlN & 241 & [34] \\
\hline 5 & Mazaheri (2013) & Pure Al & 10 vol. $\% \mathrm{~B}_{4} \mathrm{C}$ & 132 & [35] \\
\hline 6 & Selvam (2013) & AA6061 & 10 wt. $\% \mathrm{SiC}$ and $7.5 \mathrm{wt} . \%$ flyash & 213 & [36] \\
\hline 7 & Kumar (2013) & A359 & 8 wt. $\% \mathrm{Al}_{2} \mathrm{O}_{3}$ & 148 & [37] \\
\hline 8 & James, S. J. (2014) & $\mathrm{Al} 6061$ & $\mathrm{SiC}-10$ wt. $\%$ & 150.1 & [38] \\
\hline 9 & James, S. J. (2014) & Al 6061 & $\mathrm{TiB}_{2}-10 \mathrm{wt} . \%$ & 195 & [39] \\
\hline 10 & Bharath (2014) & AA6061 & 12 wt. $\% \mathrm{Al}_{2} \mathrm{O}_{3}$ & 193 & [40] \\
\hline 11 & Yang (2015) & A356 & 6 vol. $\% \mathrm{Al}_{3} \mathrm{Ti}$ & 163 & [41] \\
\hline 12 & Akbari (2015) & A356 & 3 vol. $\% \mathrm{TiB}_{2}$ & 308 & [42] \\
\hline 13 & Niranjan (2015) & A356 & 6 wt. $\% \mathrm{TiB}_{2}$ & 261 & [43] \\
\hline 14 & James, S (2017) & $\mathrm{Al} 6061$ & $\mathrm{SiC}-5$ wt. $\%, \mathrm{Al}_{2} \mathrm{O}_{3}-3$ wt. $\%, \mathrm{TiB}_{2}-2$ wt. $\%$ & 91 & [44] \\
\hline 15 & JohnyJames, S (2017) & $\mathrm{Al} 6061$ & $\mathrm{ZrSiO}_{4}-10 \mathrm{wt} . \%$ & 94 & [45] \\
\hline 16 & Ansar Kareem (2021) & AA 6061 & Iron ore of $2 \%$ & 240.5 & [46] \\
\hline 17 & Vipin Kumar Sharma (2019) & AA 6061 & $\mathrm{SiC}+\mathrm{Al}_{2} \mathrm{O}_{3}$ & 119 & [47] \\
\hline 18 & S Narendranath (2020) & AA6061 & $\mathrm{SiC} /$ fly ash $-2.5 \%$ & 145 & [48] \\
\hline 19 & S. Roseline (2018) & Al6061 & $5 \% \mathrm{ZrO}_{2}$ & 118 & [49] \\
\hline 20 & Sharma (2021) & $\mathrm{Al}-\mathrm{Mg}-\mathrm{Si}-\mathrm{T} 6$ & $\operatorname{SiC}(5 \%)+$ muscovite $(2 \%)$ & 96.08 & [50] \\
\hline 21 & Konopatsky (2021) & AlSi10 Mg & BN microflake & 230 & [51] \\
\hline 22 & Sha, Jian-jun (2021) & Al Alloy & Nickel-coated carbon fiber & 70 & [52] \\
\hline 23 & Rao (2021) & $\mathrm{Al} 7075$ & 0.5 wt. $\% \mathrm{SiC}$ & 276 & [53] \\
\hline 24 & Kumar (2021) & $\mathrm{Al}-\mathrm{SiC}$ & $\mathrm{SiC}$ & 64.55 & [54] \\
\hline 25 & Velavan (2021) & $\mathrm{Al}$ & $6 \%$ B4C + Mica & 72 & [55] \\
\hline 26 & Ezatpour (2014) & Al6061 & $\mathrm{Al}_{2} \mathrm{O}_{3}-1.5$ wt. $\%$ & 200 & [56] \\
\hline 27 & Ramnath (2014) & Al Alloy & $\mathrm{Al}_{2} \mathrm{O}_{3}-3 \% \mathrm{~B}_{4} \mathrm{C}-2 \%$ & 54.6 & [57] \\
\hline 28 & Amouri, K (2016) & A356 & 0.5 wt. $\%$ Nano-SiC & 295 & [58] \\
\hline 29 & El-Sabbagh (2013) & $6061 /$ F500 & $\mathrm{SiC}-10 \%$ & 115.66 & [59] \\
\hline 30 & Yu, L. I., et al. (2016) & AA1100 & $31 \%-B 4 C$ & 160 & [60] \\
\hline 31 & Kandpal (2017) & AA 6061 & $\mathrm{Al}_{2} \mathrm{O}_{3}-5 \%$ & 150 & [61] \\
\hline 32 & Sumankant (2017) & A356 & $\mathrm{TiB}_{2}-6 \%$ & 261.84 & [62] \\
\hline 33 & Alaneme (2013) & AA 6063 & $\mathrm{Al}_{2} \mathrm{O}_{3} \mathrm{p}-6 \%$ & 100 & [63] \\
\hline 34 & Rino (2013) & AA 6064 & $8 \%-\mathrm{ZrSiO}_{4}+2 \%-\mathrm{Al}_{2} \mathrm{O}_{3}$ & 132.98 & [64] \\
\hline 35 & Kumar, G. V (2010) & Al6061 & $\mathrm{SiC}$ & 100 & [65] \\
\hline 36 & Singh, V (2004) & AA 6061 & 5 wt. $\%$ SiCp & 52.8 & [66] \\
\hline 37 & Mazaheri, Y (2013) & $\mathrm{Al}$ & $\mathrm{TiC}-\mathrm{B} 4 \mathrm{C}$ & 123 & [35] \\
\hline
\end{tabular}

From Figure 1, the highest strength reported is by M. K Akbari et al. using metal matrix $\mathrm{A} 356$ reinforced with 3 vol. $\% \mathrm{TiB}_{2}$ that results in $308 \mathrm{MPa}$ and $\mathrm{K}$. Amouri using metal matrix A356 reinforced $0.5 \mathrm{wt} . \%$ Nano-SiC that results in $295 \mathrm{MPa}$. The lowest strength reported is by V. Singh using aluminum alloy reinforced with $5 \%$ (weight) $\mathrm{SiCp}$ that results in $52.8 \mathrm{MPa}$, and B.V Ramnath using aluminum alloy reinforced with $\mathrm{Al}_{2} \mathrm{O}_{3}-3 \% \mathrm{~B}_{4} \mathrm{C}-2 \%$ 
and achieved a tensile value of 54.6 MPa. The above experimental work listed in Table 1 shows a vast deviation in tensile strength. Various factors can cause variation in tensile strength. This work analyzes the most influential factors, i.e., wettability, uniform distribution, cluster formation, etc., in detail [31-66].

\section{Tensile strength vs. Reinforcement}

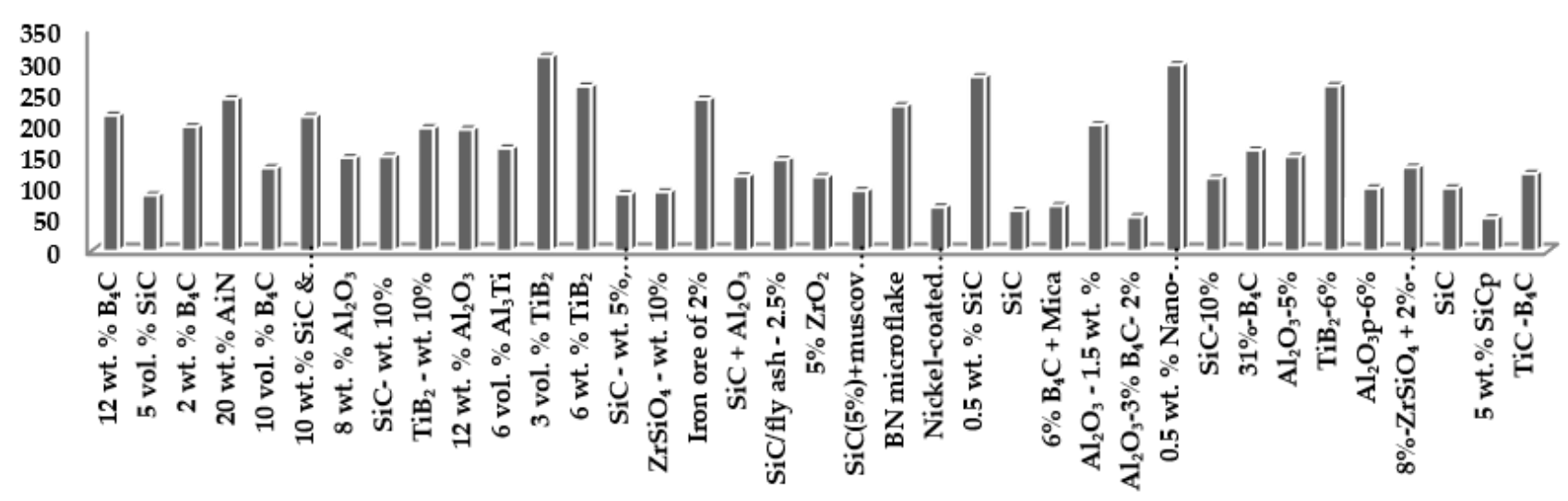

Figure 1. Graph of several reinforcements versus tensile strength [31-66].

\subsection{Analysis on Micrographs}

A microstructure exhibits the quality of bond in between the reinforcement phase and metal matrix phase. Additionally, the formation of the third phase is identified with the help of a micrograph which influences tensile strength. Holding time or temperature enables the formation of the third phase, which contributes to tensile strength. Since wettability and uniform distribution enhances tensile property, it is worth having an in-depth analysis of micrographs.

Kumar, B. A reported that clustered aluminum nitride reinforcing particles are distributed consistently in the aluminum alloy 6061 matrices, as shown in Figure 2. The proper interface is observed between the reinforcement particle and the AA6061 matrix. Mechanical property is improved due to AIN particles. The tensile strength reported is 193-241 MPa.
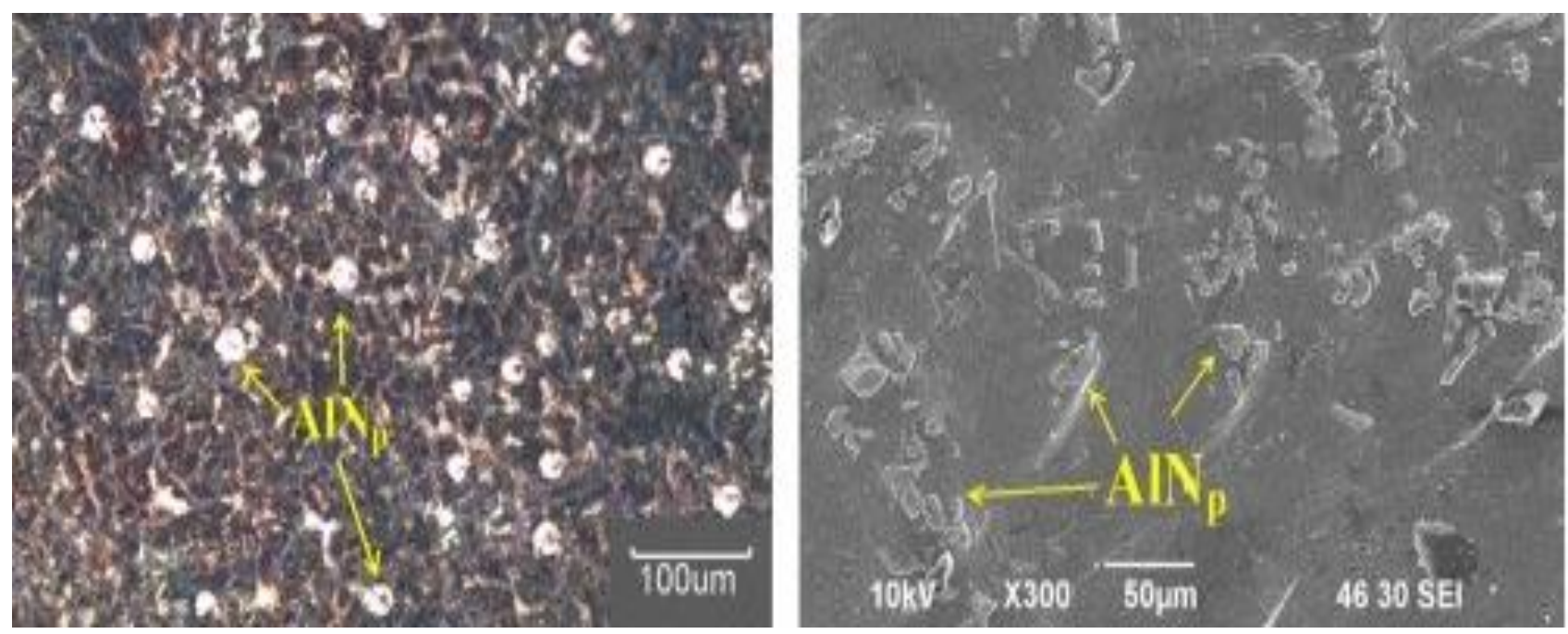

Figure 2. Micrographs of AA6061-AIN composite.

Mazaheri Y reported that the oxide film stops the aluminum melt from attaining intimate contact with the reinforcement, and the breakdown of the oxide layer at high 
temperatures is essential to attain wettability. This can be accomplished by adding flux $\mathrm{Na}_{3} \mathrm{Al} \mathrm{F}_{6}$ along with reinforcement particles to aluminum melt simultaneously. Still, particle agglomeration and uneven allocation of particles in the matrix are shown in Figure 3. Habitually, the particles created agglomerates; this can only be dispersed by high rpm stirring with limited time and proper melt temperature. The melt's enhanced wetting and complete covering of reinforcement particles by the melt can be obtained by heating $\mathrm{B}_{4} \mathrm{C}$ particles and adding flux along with $\mathrm{TiC}$ particulates. The tensile strength reported in this work is $123-132 \mathrm{MPa}$.
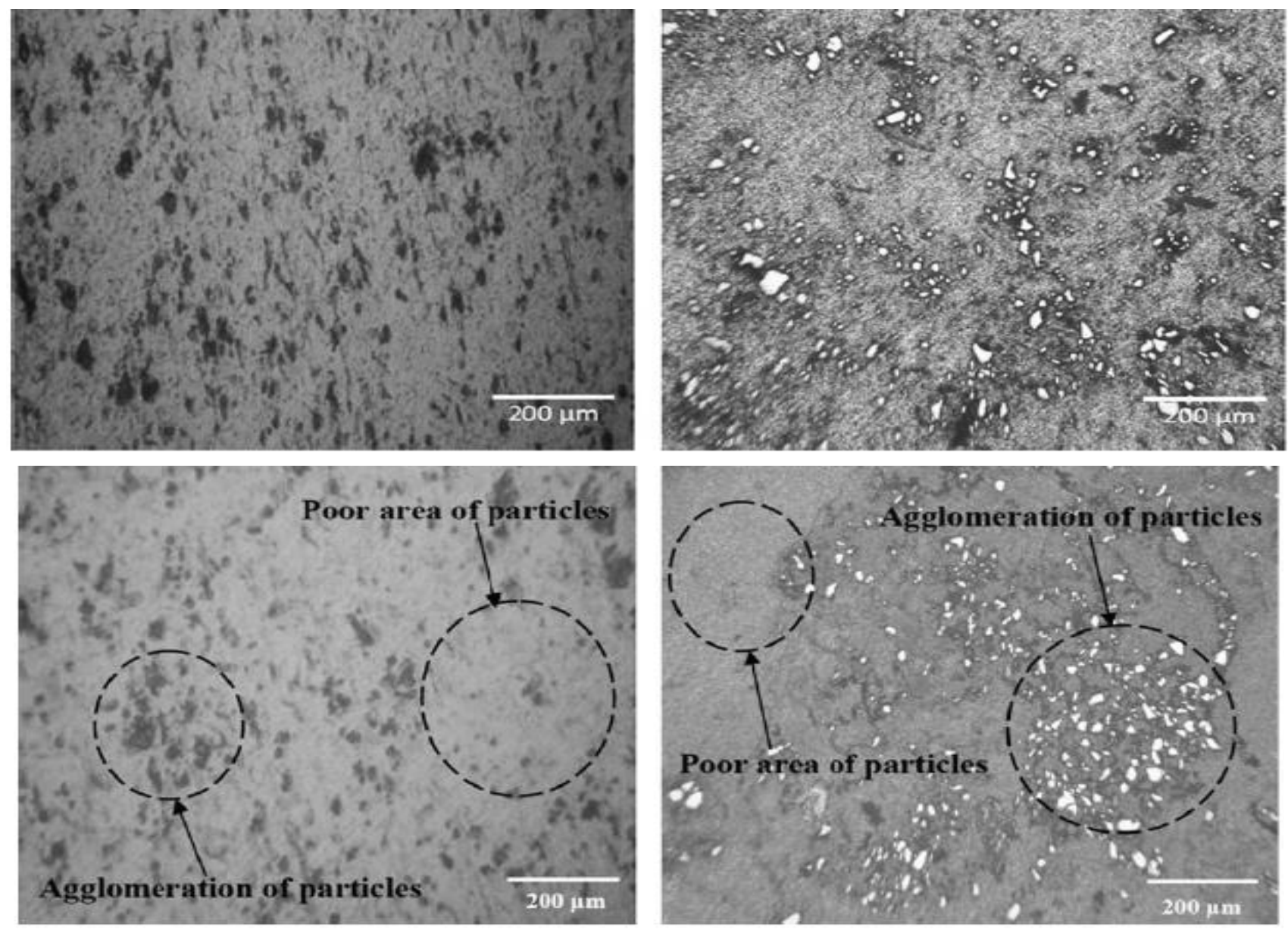

Figure 3. The micrographs of $\mathrm{Al}-\mathrm{TiC}-\mathrm{B}_{4} \mathrm{C}$ composite.

James, S. J reported that $\mathrm{TiB}_{2}$ ceramic particles are particular for superior strength; the test proves low ultimate tensile strength. This is due to the surplus cluster formation, which results in pore formation. Casting parameter components such as stirring blade speed, the temperature at the time of holding, impeller position into the melt, and the dimension of the impeller are the essential parameters that must be considered during the aluminum composite fabrication. These factors influence tensile property. Additionally, rise in weight percentage of particle reinforcement up to $15 \%$ is one of the causes for cluster formation, as shown in Figure 4. The tensile strength reported is $150.1 \mathrm{MPa}$.

Bharath $\mathrm{V}$ reported that for each composite specimen, the reinforcement phase is preheated to $200{ }^{\circ} \mathrm{C}$ and then added little by little in three steps into the vortex of aluminum 6061 alloy melt to increase wetting behavior and to achieve uniform dispersion. Microstructures of cast composites were studied by taking samples from the middle part of the casting to ensure particle dispersion. Tensile property and hardness of the developed composite specimens are measured. Micrographs of the developed composite specimen 
prove even dispersion and a little measure of grain refinement in the developed composites, as shown in Figure 5. The recorded tensile value is $193 \mathrm{MPa}$.
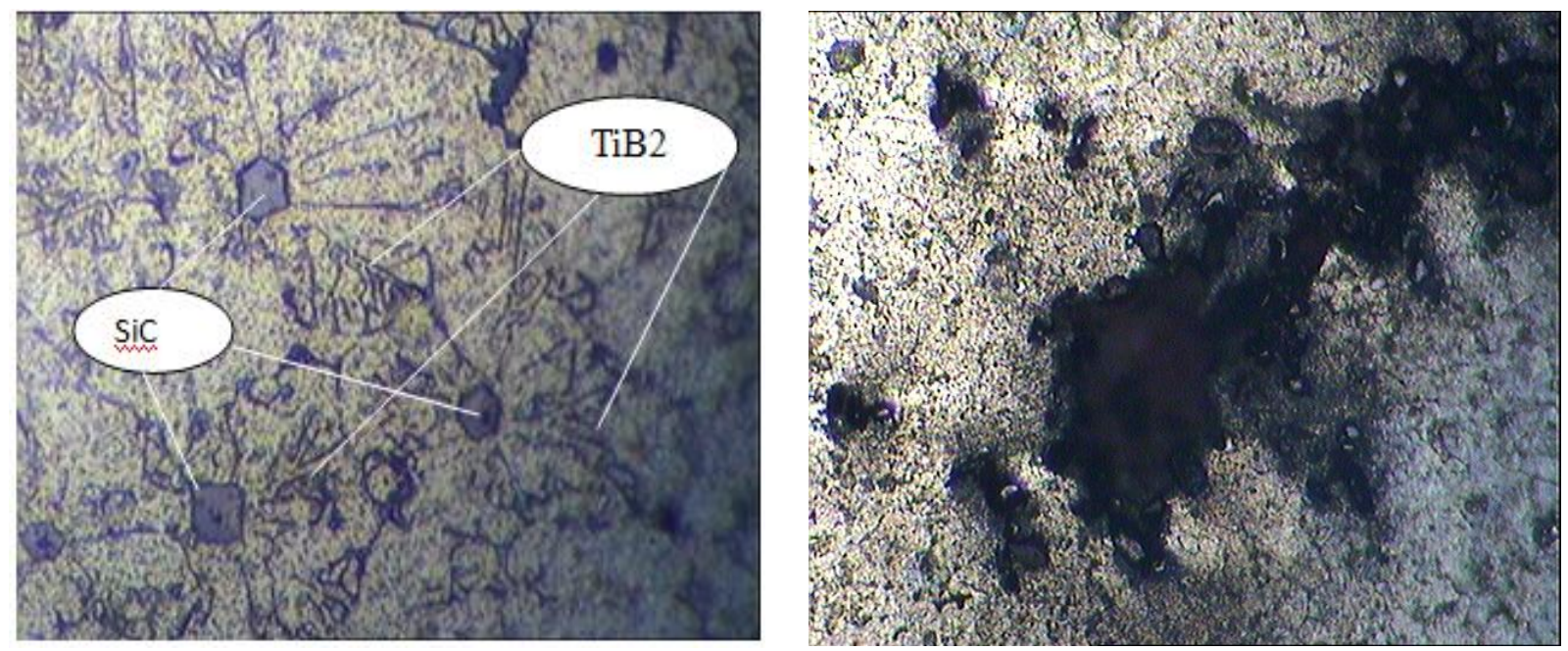

Figure 4. Micrographs of $\mathrm{AA} 6061-\mathrm{SiC}-\mathrm{TiB}_{2}$ composite.
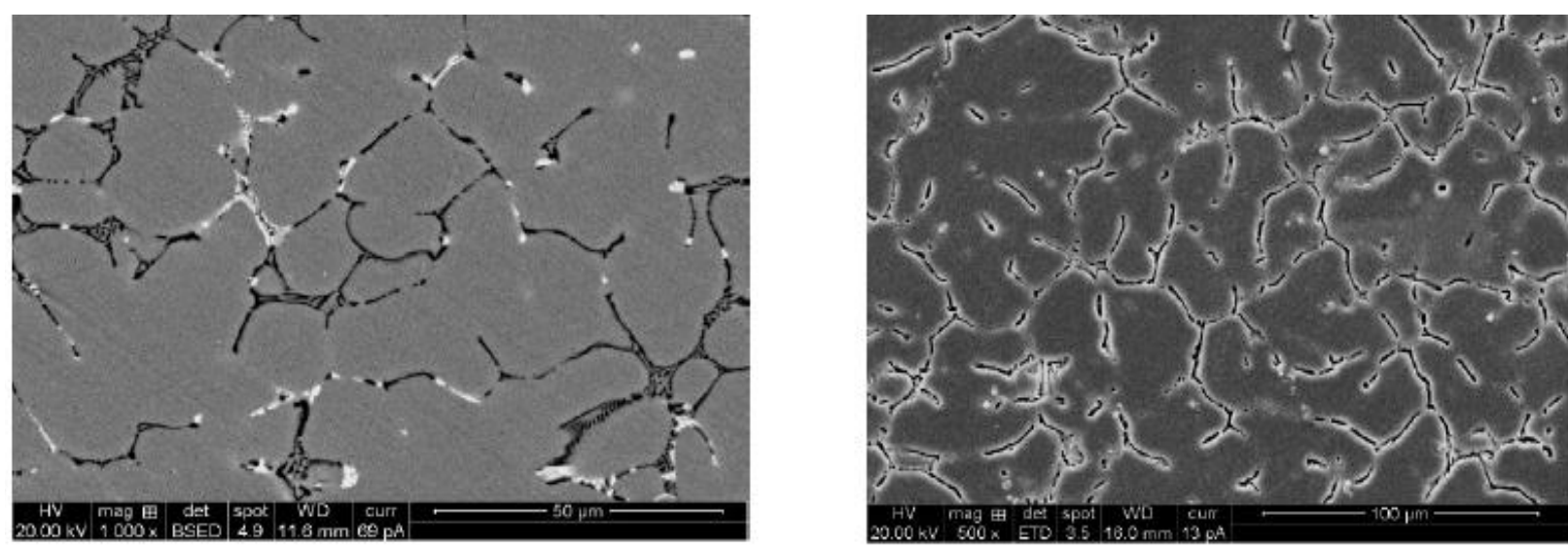

Figure 5. Micrographs of $6061 \mathrm{Al}-\mathrm{Al}_{2} \mathrm{O}_{3}$ composite.

Akbari, M. K reported that the microstructural study proves that the nanoparticles are to some extent pressed by $\mathrm{Al}$ dendrites to the uttermost freezing areas, as shown in Figure 6. Nanocomposites substantially show dissimilar tensile properties when matched up with that of the microparticle reinforced specimens. When matching up with the parent material, noteworthy enhancements in tensile strength value are recorded. Micro composites show almost lower and unvarying toughness values that match up with that of the parent material. Due to a rise in porosity content, the tensile strength of the composite substantially diminished with a rise in processing temperature. The tensile value reported is $308 \mathrm{MPa}$.

A list of factors that influence the tensile value is mentioned and discussed in detail.

\subsubsection{Selection of Metal Matrix Phase}

Thermodynamically stable dispersoids are crucial for the metal matrix composites which are to be used in the high-temperature application. This can be performed only by an alloy dispersoid arrangement in which interfacial energies, solid-state diffusivity, and elemental solubility are reduced, minimizing coarsening and interfacial reactions. Magnesium and aluminum alloys are mainly metal matrices due to their low-density value and high thermal conductivity properties. Composite with low matrix alloying additions affects an impressive combination of ductility, toughness property, and strength. A small 
amount of alloying elements is utilized in wrought alloys as grain refiners are not essential in metal matrix composites having discontinuous phases [67].
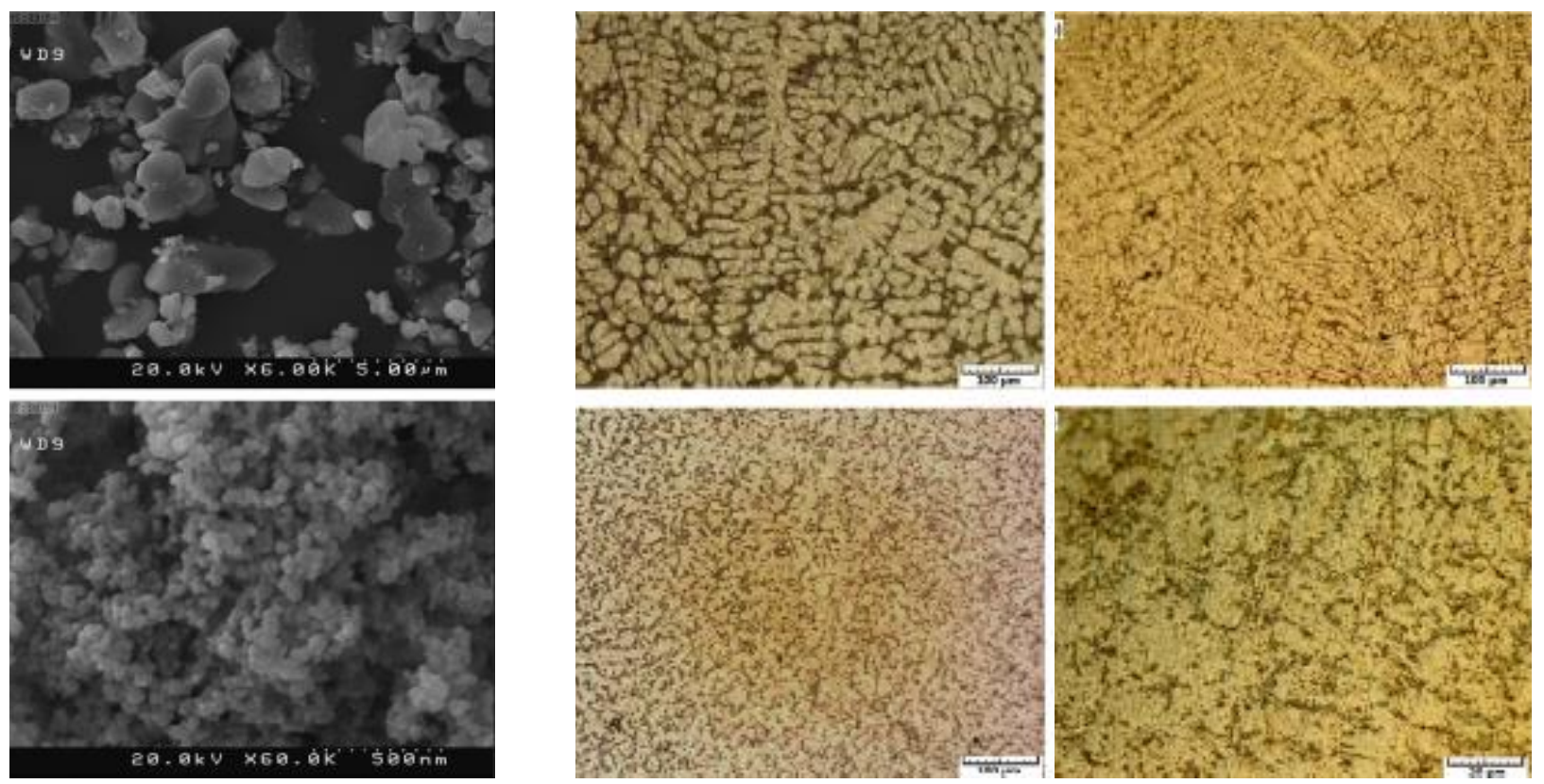

Figure 6. The micrographs of the $\mathrm{A}_{356}-\mathrm{TiB}_{2}$ composite.

Grain refiners lead to the creation of coarse intermetallic compounds at the time of consolidation, which reduces the ductility property of composite during tension. Many of the metals and alloys are good choices for matrices. Nevertheless, in practice, the preference for low-temperature applications is low. Light metals are receptive due to their low density, etc. $\mathrm{Ti}, \mathrm{Al}$, and $\mathrm{Mg}$ are the accepted matrix materials present in the application, mainly functional for defense and aircraft applications. The high strength of metal matrix materials mainly depends upon high modulus reinforcing materials. The strength-to-weight ratios of these composites are higher than in their alloy form. The preference for reinforcing materials becomes more stunted with the rise in the melting temperature of metal matrix materials. The matrix phase is a considerable material wherein ceramic reinforcing particles are dispersed and are continuous. Especially in structural purposes, the matrix phase is generally a lightweight metal such as $\mathrm{Al}, \mathrm{Mg}$, and $\mathrm{Ti}$, supporting reinforcement $[68,69]$.

\subsubsection{Preferred Property of Matrix Phase}

The preferred property of the matrix phase in a composite structure is excellent flow characteristics, minimum moisture absorption, low shrinkage, low thermal expansion, sound strength, elongation and modulus, high strength at elevated temperature, good chemical resistance, processable and dimensional stability, etc.

\subsubsection{Factors Are Taken into Account during the Selection of Matrix Phase}

During the selection of matrix phase, these are the factors that need to be taken into account. They are the matrix, and the reinforcement phase must be well-suited. Hence, if a high-strength fiber is chosen as the reinforcement phase, there is no meaning in choosing a low strength matrix phase, which fails to transmit stresses proficiently to the reinforcement phase. The matrix phase should meet the service environment such as ultra-violet, humidity, temperature, chemical, atmospheric conditions, abrasion, etc. The matrix should be compatible with the preferred casting technique. The final cast composite must be less expensive [70]. 


\subsubsection{Selection of Reinforcement Phase}

Reinforcement should give strength to the composite, which is the meaning and purpose of reinforcement. Reinforcement can also supply certain additional features of conduction, corrosive resistance and rigidity, etc. Reinforcement that decorates the matrix phase should be stiffer, more robust, and talented in converting failure to the produced composite. Or in other words, the ductility must be minimized to perform as brittle as possible. The option of reinforcing materials is further stunted with the rise in the melting temperature of matrix phases [71].

\subsubsection{Percentage Composition of Reinforcement}

The percentage of the composition of reinforcement with the metal matrix can be in volume or weight. It can be varied from 1 to $40 \%$. The increased percentage will end up with cluster formation or agglomeration. This can be prudently decided from previous related work. This work has reported 99 percent density and even distribution of reinforcement for cast composite having $15 \%$ volume fraction [72]. An increase in the composition of reinforcement particles leads to cluster formation or agglomeration.

\subsection{Size of Reinforcement}

Results of various research reveals that increases in particle size result in a reduction of the strength of the composite. The strength obtained by varying particle size by $0-20$, $40-80$, and $80-100 \mu \mathrm{m}$ is 295,195 , and $250 \mathrm{MPa}$, respectively. A decrease in particle size significantly impacts the hardening rate, which developed dislocation tangles around the particle phase. The distance between the particles $(\lambda)$ reduces smaller particle sizes at a steady quantity of reinforcement particles. Particle size reduction increases barriers against the grain boundary movement; this leads to a reduction in grain boundary movement [73-75].

\subsection{Shape of Reinforcement}

Following the theory of strain gradient of Wang-Chen, an organized investigation on the effect of particle size in metal matrix phase composite reinforced with different particle phases was performed. A detailed investigation was carried out on various composite factors, such as matrix material strain hardening exponent, particle aspect ratio, particle size, the volume fraction of particles, etc. Spheroidal and cylindrical-shaped particles were taken into account to find the strength-dependence concerning shape [76]. Shape decides the bonding between reinforcement and matrix phase.

\subsection{Wettability}

Wettability defines the amount to which a liquid will spread around a solid surface. When the liquid (matrix) flows over the reinforcement phase covering the rough surface entirely and removes all air, it is termed good wettability. Close contact between a solid and liquid may be achieved through this, provided the liquid does not possess viscosity. From this, it can be understood that wetting must occur first to have any adhesion. A high value of free energy can prevent the wetting of a liquid on a surface on the liquid surface. The balance of forces is derived from contact angle (q) or wet, as shown in Figure 7, by a Young equation [77].

\subsection{Surface Tension and Surface Chemistry}

Measurement of cohesive energy available at any interface is termed surface tension. The equation to find surface tension is stated in Equation (1). Figure 8 describes the surface tension.

$\Upsilon=F$ (force exercised parallel to the surface of the liquid in Newton)

$\mathrm{L}$ (line of action of force in meters) 


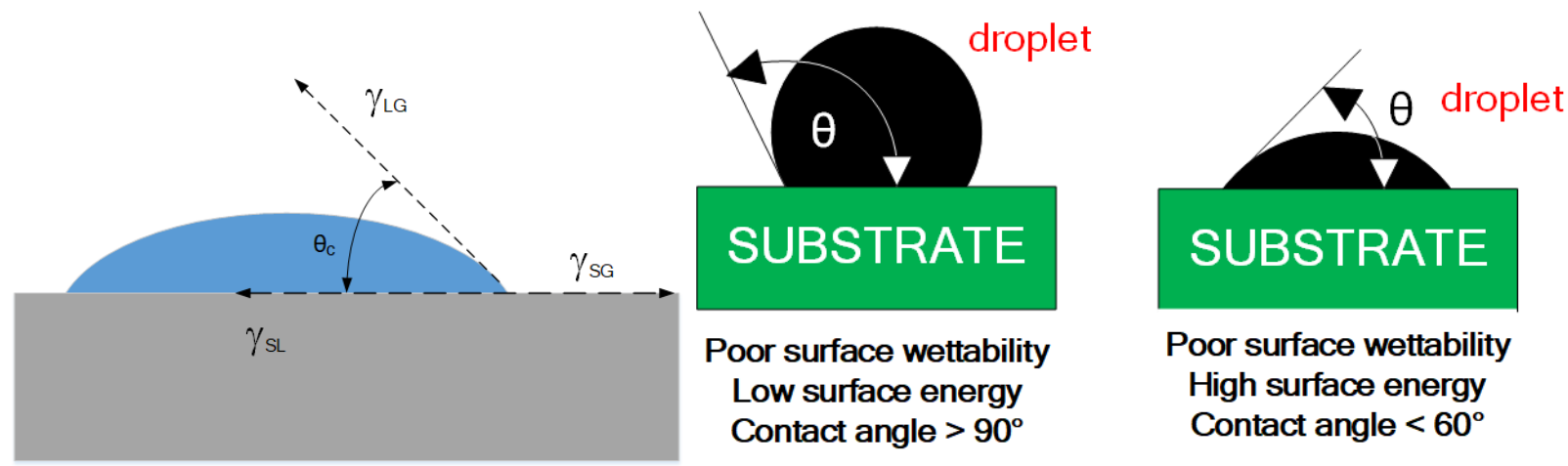

Figure 7. Wettability in terms of contact angle.

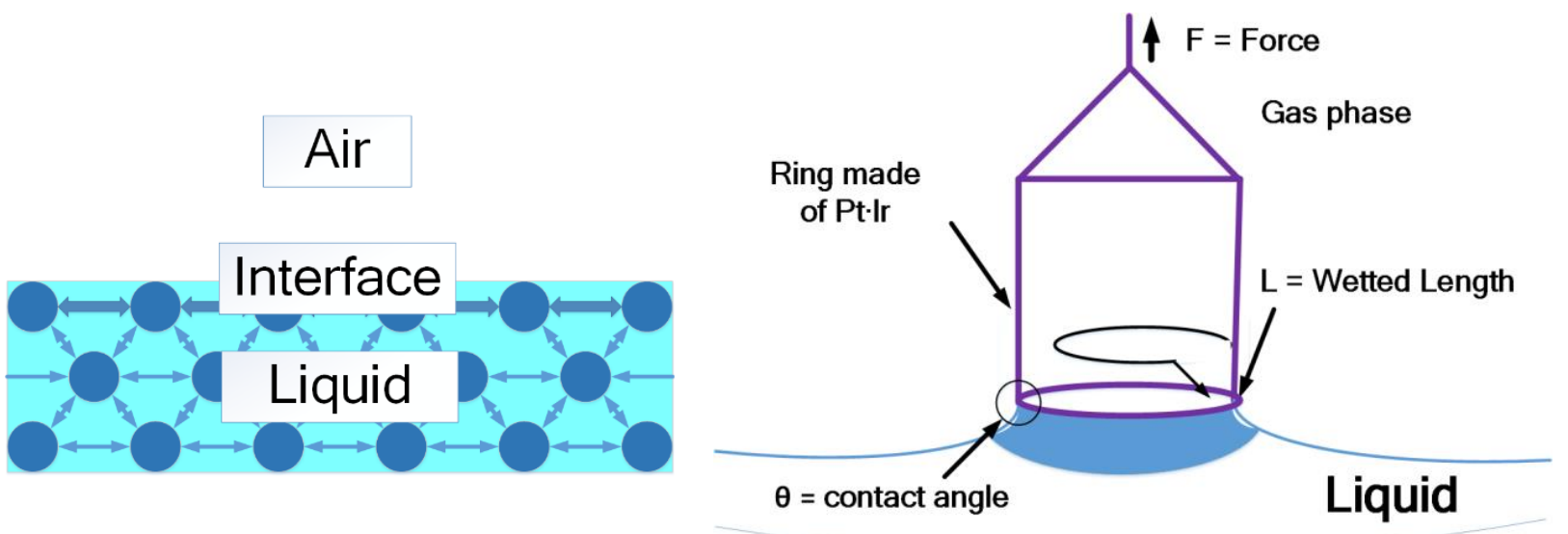

Figure 8. Surface tension.

\subsection{Interface Bonding}

Mechanical interlocking may lead to bonds of reasonable stability, depending on the roughness of the surface. Mechanical interlocking may be particularly beneficial to shear strength development, whereas it is not very stable concerning regular forces. Electrostatic bonding interaction between charges at the molecular level-act only at minimal distances [78]. Chemical bonding forms a covalent bond between matrix and reinforcement (ionic 600-1100 KJ covalent 60-700 KJ/mol).

\subsection{Prolonged Contact Time between the Matrix and Reinforcement Phase}

An interfacial chemical reaction develops undesired third phases. Formation of undesired third phases can be avoided by choosing a chemically attractive or compatible combination of materials. Additionally, elevated temperatures reduce the contact time between material phases.

One of the significant conditions in selecting constituents for composite concoction is that both matrix and reinforcement phases should be chemically inert and non-reactive. It is difficult to synthesize composites having ingredients with divergent linear expansion characteristics. When it comes to interface, the contact area between reinforcement and matrix materials is termed as interface. Particularly in some situations, the contact region is a distinct added phase. Some composites offer interphases when different surface ingredients interact with each other. Choice of synthesis method depends upon the matrix property and matrix effect upon the property of reinforcements.

\subsection{Particle Matrix Interface Energy}

The author M. Huang investigates the effect of stress concentration concerning particle shape and size. Stress concentration will be present inside the particle and at the 
interface. It is stated that normal interfacial SCF to a certain point and interfacial energy is minimum [79]. This work concludes that the interface energy affects the quality of matrix and reinforcement.

\subsection{Selection of Processing Route}

Processing metal matrix composite using stir casting will be the most straightforward and less expensive processing method [80,81].

\subsection{Stir Casting Parameters}

Stirring speed is an essential parameter because this enhances wettability between matrix and reinforcement phase and supports even circulation of reinforcement phase across the matrix. After a wide range of experiments, the optimal stirring blade speed has been concluded to be from 400 to $500 \mathrm{rpm}$. Likewise, the stirring temperature needs to be slightly higher than the metal matrix's melting point to hold the melt at the necessary viscosity level. Stirring or holding time should not be more than 5-10 min [82,83].

Kumar, M. P conducted simulation-based studies to understand the consequence of stirring blade speed on particle dispersion across the matrix phase. Silicon carbide nano reinforcement was used as a reinforcing material and copper as a metal. The simulations were performed by changing the stirrer speed from 200 to $400 \mathrm{rpm}$ while fixing other factors constant such as blade angle $60^{\circ}$ and viscosity $4.4 \mathrm{mPa} \cdot \mathrm{s}$. Particles were distributed evenly at $400 \mathrm{rpm}$ for the above parameters [84].

\subsection{Uniform Dispersion}

Achievement of uniform distribution is the main challenge in composite concoction with the help of stir casting. Uniform distribution is one of the highest influential factors on mechanical property. Judicial optimization of process parameters and selection of phases with proper composition can be achieved [85].

\subsection{Inclusion of Slag}

Usage of the bottom pouring technique is one of the methods to overcome this slag inclusion. Additionally, slag should be removed before pouring.

\subsection{The Chemical Affinity between the Metal Matrix and Reinforcement Phase}

A chemical reaction between the matrix and reinforcement phases should coincide with various other factors. If an acceptable interface bond between reinforcing materials and matrix is not obtained, this represents a failure in manufacturing. This can be due to the disparity between the physical properties of the metal matrix phase and reinforcement phase and fabrication methods. Additionally, different thermal expansion coefficients of the matrix and reinforcement can produce residual stresses in the composite during the fabrication process. If the thermal expansion coefficients are dissimilar, thermal cycling can induce stresses in the metal matrix composite. Most of the systems, including boron-magnesium, boron-aluminum, SiC-aluminum, etc., were noticed. Surface energy difference can cause poor wetting of reinforcing ceramic particles by the molten liquid metal, which leads to a weak structure in the composites.

Another problem is the formation of eutectic compounds due to the reaction between the molten metal and the particle surface. Carbon aluminum is an example of third phase formation and some other challenges. In a composite fabrication system, poor wettability is a significant challenge. Though above $1000{ }^{\circ} \mathrm{C}$ wettability increases, above $500{ }^{\circ} \mathrm{C}$ chemical reaction between aluminum and carbon will be induced, resulting in brittle aluminum carbide. Application of coatings to the reinforcement particles and by constituting alloying element controls reactions between the reinforcing particles and matrix phase since the reaction process is by diffusion.

For instance, the reaction between molten aluminum and carbon fibers can be rectified by co-deposition of boron and titanium on the carbon fiber just before composite prepara- 
tion. The painting of surface coatings on the reinforcement particles improves wettability. For example, boron fibers can be coated to develop wetting, coating of $\mathrm{B}_{4} \mathrm{C}$ on boron fibers controls reaction with aluminum and titanium matrices, and application of silicon carbide coating on boron fibers minimizes reaction in between fiber and matrix. Modifying the matrix composition will enhance wetting between the matrix and reinforcement and chemical bonding. Wetting can be enhanced by allowing selected impurities to combine or react with the fiber or particle surface, which can be wetted or spread over by the matrix material. A small quantity of about (2-3\%) of lithium into the aluminum matrix to support bond or adhesion with aluminum oxide fibers is a proven example of this method and applies to particles. Lithium reacts with alumina and forms lithium aluminates; this is easily wet by the aluminum. To enhance the wetting of carbon fibers, low melting point metals like lead, indium, and thallium can be added to aluminum [15,86-95].

\subsection{Density Difference, Viscosity, Design, and Position of Blade and Gating System}

Density differences between matrix alloys melt, and reinforcement particles result in uneven distribution of particles in the matrix phase. Additionally, various designs of blades contribute to a uniform distribution. Stirring speed can decide the transfer of reinforcement into the melt, and it can hold the reinforcement particles in a condition of suspension. The position of the stirrer from the bottom of the furnace affects uniform distribution. The stirrer should be placed so that $35 \%$ of liquid should be under the stirrer and $65 \%$ liquid should be above the stirrer. Additionally, fabrication temperature influences the melt viscosity. The uniform particle distribution varies concerning viscosity change. Structure formation during solidification is influenced by pouring temperature, which decides the metal flow rate. A proper gating system needs to be arranged to have a free melt flow $[96,97]$.

\subsection{Casting Environment}

Stirring blade speed and stirring time reflect in the microstructure formation during casting. The even allocation of reinforcement particles across the aluminum matrix relies primarily on stir casting parameters and rate of cooling concerning the type of casting method employed. A quick-quench compo caster is recommended while processing hightemperature materials.

\subsection{Rearrangement of the Reinforcement Particles during Solidification}

Theoretical models predict the pre-settling of nanoparticles at slower rates. Various experiments prove that the melt matrix temperature has an impact on the settling behavior during casting. Conducted experiments depict the inverse relationship between the Vol fraction of reinforcing materials and temperature near melting point with settling rate. The viscosity of both metal and reinforcing material mix reduces as the melt mixture temperature increases. Due to this viscosity reduction, the reinforcement particle phases try to stay down concerning volume or weight percent composition. During solidification settling, time must be minimized [98-101].

\subsection{Accuracy of Experiments}

There are so many factors that decide the reliability of tensile values. This includes the trustworthiness of certified purity of reinforcement and matrix, accuracy and precision of the testing machine, number of samples tested, and its calculations-the specimen size, whether macro or micro, decides tensile results. The specimen can be made from the best part of the cast sample. The genuineness of the values also reported a critical concern [102].

\section{Conclusions}

Tensile property is one of the vital properties among the other mechanical properties for a metal matrix composite. It can be achieved by judicial selection of metal matrix, i.e., type of aluminum. Reinforcement selection too plays a vital role in the strength of processed composite. Besides these, the casting techniques, i.e., stir casting or stir casting, 
coupled with squeeze casting, are influential factors. The stir casting parameters need to be judicially selected and optimized to obtain uniform distribution and excellent wettability. This factor decides the tensile property of the processed composite. The formation of the third phase also has considerable influence on the tensile property of processed metal matrix composite.

Author Contributions: Conceptualization, A.R.A. and J.J.; methodology, A.R.A., A.M. and J.J.; formal analysis, J.J.; A.R.A.; A.M. and C.-P.J.; investigation, C.-P.J., A.R.A. and A.M.; resources, A.R.A. and C.-P.J.; data curation, J.J. and A.R.A.; writing, J.J. and A.R.A.; writing-review and editing, J.J., A.M. and A.R.A.; supervision, A.R.A., A.M. and C.-P.J.; project administration, A.R.A. and C.-P.J.; funding acquisition, C.-P.J. All authors have read and agreed to the published version of the manuscript.

Funding: This research was funded by Ministry of Science and Technology of China (Taiwan), under grant numbers MOST 109-2221-E-194-011-MY2 and MOST 109-2923-E-194-002-MY3.

Data Availability Statement: The data will be shared upon request from the authors.

Conflicts of Interest: The authors declare that there is no conflict of interest.

\section{References}

1. Haghshenas, M. Metal-Matrix composites. Ref. Modul. Mater. Sci. Mater. Eng. 2016, 35, 03950-3.

2. Haghshenas, M. Reference Module in Materials Science and Materials Engineering; Chapter Metal-Matrix Composites; Elsevier: Amsterdam, The Netherlands, 2016; pp. 1-28.

3. Liu, W.; Webster, T.J. Toxicity and biocompatibility properties of nanocomposites for musculoskeletal tissue regeneration. In Nanocomposites for Musculoskeletal Tissue Regeneration; Woodhead Publishing: Cambridge, UK, 2016; pp. 95-122.

4. Aramesh, M. Machinability of Titanium Metal Matrix Composites (Ti-MMCs). Ph.D. Thesis, École Polytechnique de Montréal, Montréal, QC, Canada, 2015.

5. Congress, U.S. Advanced Materials by Design; US Government Printing Office: Washington, DC, USA, 1988.

6. Mahmood, M.A.; Popescu, A.C.; Mihailescu, I.N. Metal matrix composites synthesized by laser-melting deposition: A review. Materials 2020, 13, 2593. [CrossRef] [PubMed]

7. Rajak, D.K.; Pagar, D.D.; Menezes, P.L.; Linul, E. Fiber-reinforced polymer composites: Manufacturing, properties, and applications. Polymers 2019, 11, 1667. [CrossRef] [PubMed]

8. Molina, J.M.; Rhême, M.; Carron, J.; Weber, L. Thermal conductivity of aluminum matrix composites reinforced with mixtures of diamond and SiC particles. Scr. Mater. 2008, 58, 393-396. [CrossRef]

9. Bello, S.A. Wear and thermal resistance properties of aluminium particulate micro composites. Bull. Mater. Sci. 2020, 43, 1-15. [CrossRef]

10. Kallip, K. High Strength Ductile Aluminium Matrix Composite; Tallinn University of Technology: Tallinn, Estonia, 2017; ISBN 978-9949-83-175-3.

11. Sharma, A.K.; Bhandari, R.; Aherwar, A.; Rimašauskienė, R.; Pinca-Bretotean, C. A study of advancement in application opportunities of aluminum metal matrix composites. Mater. Today Proc. 2020, 26, 2419-2424. [CrossRef]

12. Swamy, P.K.; Mylaraiah, S.; GowdruChandrashekarappa, M.P.; Lakshmikanthan, A.; Pimenov, D.Y.; Giasin, K.; Krishna, M. Corrosion Behaviour of High-Strength Al 7005 Alloy and Its Composites Reinforced with Industrial Waste-Based Fly Ash and Glass Fibre: Comparison of Stir Cast and Extrusion Conditions. Materials 2021, 14, 3929. [CrossRef] [PubMed]

13. Vasiliev, V.V.; Morozov, E.V. Advanced Mechanics of Composite Materials and Structural Elements; Newnes: London, UK, 2013.

14. MMCs. Piston, piston ring, connecting rod, brake rotor, cylinder liner bearings, bushings, etc. In Automotive Applications for MMC's Based on Short-Staple Alumina Fibres; Dinwoodie, J., Ed.; SAE Transactions: New York, NY, USA, 1987; pp. $269-279$.

15. Hashim, J.; Looney, L.; Hashmi, M.S.J. Metal matrix composites: Production by the stir casting method. J. Mater. Process. Technol. 1999, 92, 1-7. [CrossRef]

16. Surappa, M.K. Microstructure evolution during solidification of DRMMCs (discontinuously reinforced metal matrix composites): State of the art. J. Mater. Process. Technol. 1997, 63, 325-333. [CrossRef]

17. Skibo, M.; Morris, P.L.; Lloyd, D.J. Structure and properties of liquid metal processed SiC reinforced aluminium. In Proceedings of the World Materials Congress, Chicago, IL, USA, 24-30 September 1988; pp. 257-262.

18. Iqbal, A.A.; Nuruzzaman, D.M. Effect of the reinforcement on the mechanical properties of aluminium matrix composite: A review. Int. J. Appl. Eng. Res. 2016, 11, 10408-10413.

19. Abdizadeh, H.; Baghchesara, M.A. Investigation into the mechanical properties and fracture behavior of A356 aluminum alloy-based $\mathrm{ZrO}_{2}$-particle-reinforced metal-matrix composites. Mech. Compos. Mater. 2013, 49, 571-576. [CrossRef]

20. Baghchesara, M.A.; Abdizadeh, H.; Baharvandi, H.R. Fractography of stir-casted $\mathrm{Al}-\mathrm{ZrO}_{2}$ composites. Iran. J. Sci. Technol. Trans. B Eng. 2009, 33, 453-462.

21. Hajizamani, M.; Baharvandi, H. Fabrication and studying the mechanical properties of $\mathrm{A} 356$ alloy reinforced with $\mathrm{Al}_{2} \mathrm{O}_{3}-10 \% \mathrm{Vol}$. $\mathrm{ZrO}_{2}$ nanoparticles through stir casting. Adv. Mater. Phys. Chem. 2011, 1, 26-30. [CrossRef] 
22. Karthikeyan, G.; Jinu, G.R. Dry Sliding Wear Behaviour of Stir Cast LM25/ZrO 2 Metal Matrix Composites. Trans. FAMENA 2016, 39, 89-98.

23. Prajval, S.; Prasad, P.R. Synthesis and evaluation of mechanical properties of aluminium A356 alloy reinforced with mica and titanium dioxide hybrid composite at different aging conditions. Int. J. Adv. Res. Eng. Appl. Sci. 2016, 5, 13-21.

24. Rajmohan, T.; Palanikumar, K.; Ranganathan, S. Evaluation of mechanical and wear properties of hybrid aluminium matrix composites. Trans. Nonferrous Met. Soc. China 2013, 23, 2509-2517. [CrossRef]

25. Raj, R.; Thakur, D.G. Qualitative and quantitative assessment of microstructure in Al-B4C metal matrix composite processed by modified stir casting technique. Arch. Civ. Mech. Eng. 2016, 16, 949-960. [CrossRef]

26. Beyrami, B.P.; Abdizadeh, H.; Baharvandi, H.R.; Bonab, M.M. The Effect of Composition and Stir-Casting Parameters on the Mechanical Properties of $\mathrm{Al} / \mathrm{ZrO} 2 \mathrm{p}$ Nanocomposites. In Proceedings of the 13th European Conference on Composite Materials, Stockholm, Sweden, 2-5 June 2008.

27. Malhotra, S.; Narayan, R.; Gupta, R.D. Synthesis and characterization of Aluminium 6061 alloy—Fly ash \& zirconia metal matrix composite. Int. J. Curr. Eng. Technol. 2013, 3, 1716-1719.

28. Ramachandra, M.; Maruthi, G.D.; Rashmi, R. Evaluation of Corrosion Property of Aluminium-Zirconium Dioxide (AlZrO 2 ) Nanocomposites. Evaluation 2016, 1, 56412.

29. Patoliya, D.M.; Sharma, S.; Student, P.G. Preparation and Characterization of Zirconium Dioxide Reinforced Aluminium Metal Matrix Composites. Eng. Technol. 2015, 4, 3315-3321.

30. Thyla, P.R.; Tiruvenkadam, N.; Kumar, M.S. Investigation of Corrosion Behavior of Light Weight NanoHybrid $\mathrm{Al}^{6061-Z r O}{ }_{2}-\mathrm{SiC}-$ Gr Composites. Int. J. Chem. Technol. Res. 2015, 8, 312-316.

31. Kalaiselvan, K.; Murugan, N.; Parameswaran, S. Production and characterization of AA6061-B 4 C stir cast composite. Mater. Des. 2011, 32, 4004-4009. [CrossRef]

32. Amirkhanlou, S.; Jamaati, R.; Niroumand, B.; Toroghinejad, M.R. Manufacturing of high-performance Al356/SiCp composite by CAR process. Mater. Manuf. Process. 2011, 26, 902-907. [CrossRef]

33. Alizadeh, A.; Taheri-Nassaj, E.; Hajizamani, M. The hot extrusion process affects the mechanical behavior of stir cast Al-based composites reinforced with mechanically milled B4C nanoparticles. J. Mater. Sci. Technol. 2011, 27, 1113-1119. [CrossRef]

34. Kumar, B.A.; Murugan, N. Metallurgical and mechanical characterization of stir cast AA6061-T6-AlN p composite. Mater. Des. 2012, 40, 52-58. [CrossRef]

35. Mazaheri, Y.; Meratian, M.; Emadi, R.; Najarian, A.R. Comparison of microstructural and mechanical properties of Al-TiC, $\mathrm{Al}-\mathrm{B}_{4} \mathrm{C}$, and $\mathrm{Al}-\mathrm{TiC}-\mathrm{B}_{4} \mathrm{C}$ composites prepared by casting techniques. Mater. Sci. Eng. A 2013, 560, 278-287. [CrossRef]

36. Selvam, J.D.R.; Smart, D.R.; Dinaharan, I. Synthesis and characterization of Al6061-Fly Ashp-SiCp composites by stir casting and compo casting methods. Energy Procedia 2013, 34, 637-646. [CrossRef]

37. Kumar, A.; Lal, S.; Kumar, S. Fabrication and characterization of $\mathrm{A} 359 / \mathrm{Al}_{2} \mathrm{O}_{3}$ metal matrix composite using electromagnetic stir casting method. J. Mater. Res. Technol. 2013, 2, 250-254. [CrossRef]

38. James, S.J.; Venkatesan, K.; Kuppan, P.; Ramanujam, R. Hybrid aluminium metal matrix composite reinforced with $\mathrm{SiC}_{\text {and }} \mathrm{TiB} 2$. Procedia Eng. 2014, 97, 1018-1026. [CrossRef]

39. James, S.J.; Venkatesan, K.; Kuppan, P.; Ramanujam, R. Comparative study of composites reinforced with $\mathrm{SiC}_{\text {and }} \mathrm{TiB}_{2}$. Procedia Eng. 2014, 97, 1012-1017. [CrossRef]

40. Bharath, V.; Nagaral, M.; Auradi, V.; Kori, S.A. Preparation of $6061 \mathrm{Al}-\mathrm{Al}_{2} \mathrm{O}_{3} \mathrm{MMC}^{\prime}$ s by Stir Casting and Evaluation of Mechanical and Wear Properties. Procedia Mater. Sci. 2014, 6, 1658-1667. [CrossRef]

41. Yang, R.; Zhang, Z.; Zhao, Y.; Chen, G.; Guo, Y.; Liu, M.; Zhang, J. Effect of multi-pass friction stir processing on microstructure and mechanical properties of Al 3 Ti/A356 composites. Mater. Charact. 2015, 106, 62-69. [CrossRef]

42. Akbari, M.K.; Baharvandi, H.R.; Shirvanimoghaddam, K. Tensile and fracture behavior of nano/ $\mathrm{micro} \mathrm{TiB}_{2}$ particle reinforced casting A356 aluminum alloy composites. Mater. Des. (1980-2015) 2015, 66, 150-161. [CrossRef]

43. Rajaravi, C.; Niranjan, K.; Lakshminarayanan, P.R. Comparative Analysis of Al/TiB2 Metal Matrix Composites in Different Mould Conditions. J. Adv. Microsc. Res. 2015, 10, 260-264. [CrossRef]

44. James, S.; Annamalai, A.; Kuppan, P.; Oyyaravelu, R. Fabrication of Hybrid Metal Matrix Composite Reinforced WithSiC $/ \mathrm{Al}_{2} \mathrm{O}_{3} / \mathrm{TiB}_{2}$. Mech. Mater. Sci. Eng. MMSE J. Open Access 2017. [CrossRef]

45. Johnyjames, S.; Annamalai, A. Fabrication of Aluminium Metal Matrix Composite and Testing of Its Property. Mech. Mater. Sci. Eng. MMSE J. Open Access 2017, 9, 306-311. [CrossRef]

46. Kareem, A.; Qudeiri, J.A.; Abdudeen, A.; Ahammed, T.; Ziout, A. A review on AA 6061 metal matrix composites produced by stir casting. Materials 2021, 14, 175. [CrossRef]

47. Sharma, V.K.; Kumar, V.; Joshi, R.S. Investigation of rare earth particulate on tribological and mechanical properties of Al-6061 alloy composites for aerospace application. J. Mater. Res. Technol. 2019, 8, 3504-3516. [CrossRef]

48. Narendranath, S.; Chakradhar, D. Studies on microstructure and mechanical characteristics of as-cast AA6061/SiC/fly ash hybrid AMCs produced by stir casting. Mater. Today Proc. 2020, 20, A1-A5.

49. Roseline, S.; Paramasivam, V.; Anandhakrishnan, R.; Lakshminarayanan, P.R. Numerical evaluation of zirconium reinforced aluminium matrix composites for a sustainable environment. Ann. Oper. Res. 2019, 275, 653-667. [CrossRef] 
50. Sharma, S.; Singh, J.; Gupta, M.K.; Mia, M.; Dwivedi, S.P.; Saxena, A.; Korkmaz, M.E. Investigation on mechanical, tribological, and microstructural properties of Al-Mg-Si-T6/SiC/muscovite-hybrid metal-matrix composites for high strength applications. J. Mater. Res. Technol. 2021, 12, 1564-1581. [CrossRef]

51. Konopatsky, A.S.; Kvashnin, D.G.; Corthay, S.; Boyarintsev, I.; Firestein, K.L.; Orekhov, A.; Shtansky, D.V. Microstructure evolution during AlSi10Mg molten alloy/B.N. micro flakes interactions in metal matrix composites obtained through 3D printing. J. Alloys Compd. 2021, 859, 157765. [CrossRef]

52. Sha, J.J.; LÜ, Z.Z.; Sha, R.Y.; Zu, Y.F.; Dai, J.X.; Xian, Y.Q.; Yan, C.L. Improved wettability and mechanical properties of metalcoated carbon-fiber-reinforced aluminum matrix composites by squeeze melt infiltration technique. Trans. Nonferrous Met. Soc. China 2021, 31, 317-330. [CrossRef]

53. Rao, T.B. Microstructural, mechanical, and wear properties characterization, and strengthening mechanisms of Al7075/SiCnp composites processed through ultrasonic cavitation assisted stir-casting. Mater. Sci. Eng. A 2021, 805, 140553. [CrossRef]

54. Kumar, M.S.; Begum, S.R.; Pruncu, C.I.; Asl, M.S. Role of homogeneous distribution of SiC reinforcement on the characteristics of stir cast Al-SiC composites. J. Alloys Compd. 2021, 869, 159250. [CrossRef]

55. Velavan, K.; Palanikumar, K.; Natarajan, E.; Lim, W.H. Implications on the influence of mica on the mechanical properties of cast hybrid (Al+ 10\% B4C+ Mica) metal matrix composite. J. Mater. Res. Technol. 2021, 10, 99-109. [CrossRef]

56. Ezatpour, H.R.; Sajjadi, S.A.; Sabzevar, M.H.; Huang, Y. Investigation of microstructure and mechanical properties of Al6061nanocomposite fabricated by stir casting. Mater. Des. 2014, 55, 921-928. [CrossRef]

57. Ramnath, B.V.; Elanchezhian, C.; Jaivignesh, M.; Rajesh, S.; Parswajinan, C.; Ghias, A.S.A. Evaluation of mechanical properties of aluminium alloy-alumina-boron carbide metal matrix composites. Mater. Des. 2014, 58, 332-338. [CrossRef]

58. Amouri, K.; Kazemi, S.; Momeni, A.; Kazazi, M. Microstructure and mechanical properties of Al-nano/micro SiC composites produced by stir casting technique. Mater. Sci. Eng. A 2016, 674, 569-578. [CrossRef]

59. El-Sabbagh, A.M.; Soliman, M.; Taha, M.A.; Palkowski, H. Effect of rolling and heat treatment on tensile behavior of wrought Al-SiCp composites prepared by stir-casting. J. Mater. Process. Technol. 2013, 213, 1669-1681. [CrossRef]

60. Yu, L.I.; Li, Q.L.; Dong, L.I.; Wei, L.I.U.; Shu, G.G. Fabrication and characterization of stir casting AA6061-31\% B ${ }_{4}$ C composite. Trans. Nonferrous Met. Soc. China 2016, 26, 2304-2312.

61. Kandpal, B.C.; Singh, H. Fabrication and characterization of $\mathrm{Al}_{2} \mathrm{O}_{3}$ /aluminium alloy 6061 composites fabricated by Stir casting. Mater. Today Proc. 2017, 4, 2783-2792. [CrossRef]

62. Sumankant, Y.; Jawalkar, C.S.; Verma, A.S.; Surie, N.M. Fabrication of aluminium metal matrix composites with particulate reinforcement: A review. Mater. Today 2017, 4, 2927-2936.

63. Alaneme, K.K.; Bodunrin, M.O. Mechanical behavior of alumina reinforced AA 6063 metal matrix composites developed by two step-stir casting process. Acta Tech. Corviniensis-Bull. Eng. 2013, 6, 105.

64. Rino, J.J.; Sivalingappa, D.; Koti, H.; Jebin, V.D. Properties of Al6063 MMC reinforced with zircon sand and alumina. IOSR J. Mech. Civ. Eng. 2013, 5, 72-77. [CrossRef]

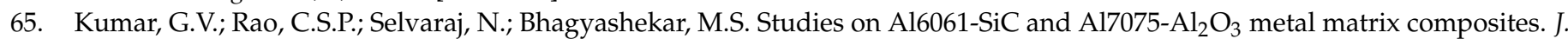
Miner. Mater. Charact. Eng. 2010, 9, 43-55.

66. Singh, V.; Prasad, R.C. Tensile and fracture behavior of 6061 al-sicp metal matrix composites. In Proceedings of the International Symposium of Research Students on Materials Science and Engineering, Madras, India, 20-22 December 2004; pp. $20-22$.

67. Azarniya, A.; Azarniya, A.; Abdollah-zadeh, A.; Madaah Hosseini, H.R.; Ramakrishna, S. In situ hybrid aluminum matrix composites: A review of phase transformations and mechanical aspects. Adv. Eng. Mater. 2019, 21, 1801269. [CrossRef]

68. Awotunde, M.A.; Adegbenjo, A.O.; Obadele, B.A.; Okoro, M.; Shongwe, B.M.; Olubambi, P.A. Influence of sintering methods on the mechanical properties of aluminum nanocomposites reinforced with carbonaceous compounds: A review. J. Mater. Res. Technol. 2019, 8, 2432-2449. [CrossRef]

69. Fan, J.; Njuguna, J. An introduction to lightweight composite materials and their use in transport structures. In Lightweight Composite Structures in Transport; Woodhead Publishing: Cambridge, UK, 2016; pp. 3-34.

70. Nturanabo, F.; Masu, L.; Kirabira, J.B. Novel applications of aluminium metal matrix composites. Alum. Alloy. Compos. 2019. [CrossRef]

71. Rajak, D.K.; Pagar, D.D.; Kumar, R.; Pruncu, C.I. Recent progress of reinforcement materials: A comprehensive overview of composite materials. J. Mater. Res. Technol. 2019, 8, 6354-6374. [CrossRef]

72. Diler, E.A.; Ghiami, A.; Ipek, R. Effect of high ratio of reinforcement particle size to matrix powder size and volume fraction on microstructure, densification, and tribological properties of $\mathrm{SiC}$ p reinforced metal matrix composites manufactured via a hot pressing method. Int. J. Refract. Met. Hard Mater. 2015, 52, 183-194. [CrossRef]

73. Manoharan, M.; Lewandowski, J.J. Effect of reinforcement size and matrix microstructure on the fracture properties of an aluminum metal matrix composite. Mater. Sci. Eng. A 1992, 150, 179-186. [CrossRef]

74. Lewandowski, J.J.; Liu, D.S.; Liu, C. Observations on the effects of particulate size and superposed pressure on deformation of metal matrix composites. Scr. Metall. Mater. 1991, 25, 21-26. [CrossRef]

75. Kamat, S.V.; Hirth, J.P.; Mehrabian, R. Mechanical properties of particulate-reinforced aluminum-matrix composites. Acta Metall. 1989, 37, 2395-2402. [CrossRef]

76. Chen, S.H.; Wang, T.C. Size effects in the particle-reinforced metal-matrix composites. Acta Mech. 2002, 157, 113-127. [CrossRef]

77. von Fraunhofer, J.A. Adhesion and cohesion. Int. J. Dent. 2012, 2012, 951324. [CrossRef] 
78. Libanori, R.; Carnelli, D.; Rothfuchs, N.; Binelli, M.R.; Zanini, M.; Nicoleau, L.; Feichtenschlager, B.; Albrecht, G.; Studart, A.R. Composites reinforced via mechanical interlocking of surface-roughened microplatelets within ductile and brittle matrices. Bioinspiration Biomim. 2016, 11, 036004. [CrossRef] [PubMed]

79. Huang, M.; Li, Z. Influences of particle size and interface energy on the stress concentration induced by the oblate spheroidal particle and the void nucleation mechanism. Int. J. Solids Struct. 2006, 43, 4097-4115. [CrossRef]

80. Jokhio, M.H.; Panhwer, M.I.; Unar, M.A. Manufacturing of aluminum composite material using a stir casting process. arXiv 2016, arXiv:1604.01251.

81. Rajendra, K.; Babu, M.V.S.; Rao, P.G.; Suman, K.N.S. Recent Developments in the Fabrication of Metal Matrix Composites by Stir Casting Route: A Review. Int. J. Chem. Sci. 2016, 14, 2358-2366.

82. Sozhamannan, G.G.; Prabu, S.B.; Venkatagalapathy, V.S.K. Effect of processing parameters on metal matrix composites: Stir casting process. J. Surf. Eng. Mater. Adv. Technol. 2012, 2, 11.

83. Arulraj, M.; Palani, P.K.; Venkatesh, L. Optimization of process parameters in stir casting of hybrid metal matrix $\left(\mathrm{LM} 25 / \mathrm{SiC} / \mathrm{B}_{4} \mathrm{C}\right)$ Composite using Taguchi method. J. Adv. Chem. 2017, 13, 6475-6479. [CrossRef]

84. Kumar, M.P.; Babu, M.S.; Ramana, V.S.N.V. Simulation of Stir Casting Process Using Computational Fluid Dynamics. Int. J. Eng. Res. Appl. 2015, 5, 132-135.

85. Saravanan, C.; Subramanian, K.; Krishnan, V.A.; Narayanan, R.S. Effect of Particulate Reinforced Aluminium Metal Matrix Composite-A Review. Mech. Mech. Eng. 2015, 19, 23-30.

86. Chawla, K.K.; Metzger, M. Initial dislocation distributions in tungsten fiber-copper composites. J. Mater. Sci. 1972, 7, 34-39. [CrossRef]

87. Chappell, P.J. Reinforcement-Matrix Interface Effects in Metal Matrix Composites (No.MRL-TN-562); Materials Research Labs Ascot Vale: Victoria, Australia, 1989.

88. Vogelsang, M.; Arsenault, R.J.; Fisher, R.M. Anin situ HVEM study of dislocation generation at Al/SiC interfaces in metal matrix composites. Metall. Mater. Trans. A 1986, 17, 379-389. [CrossRef]

89. Rhee, S.K. Wetting of ceramics by liquid aluminum. J. Am. Ceram. Soc. 1970, 53, 386-389. [CrossRef]

90. Baker, A.A.; Shipman, M.C.; Cripwell, P.A.; Jackson, P.W. Oxidation of aluminum-coated carbon fibers and carbon-aluminum composites. Fibre Sci. Technol. 1972, 5, 285-302. [CrossRef]

91. Meyerer, W.; Kizer, D.; Paprocki, S.; Paul, H. Versatility of GraphiteAluminum Composites. In Proceedings of the Second International Conference on Composites Materials, Toronto, ON, Canada, 16-20 April 1978; TS-AIME: New York, NY, USA, 1978; p. 141.

92. Katzman, H.A. Fiber coatings for the fabrication of graphite-reinforced magnesium composites. J. Mater. Sci. 1987, 22, 144-148. [CrossRef]

93. Naslain, R.; Thebault, J.; Pailler, R. Chemical Compatibility in Metal/B Composites. In Proceedings of the 1975 International Conference on Composite Materials, Geneva, Switzerland, 7-11 April 1975; TMS-AIME: New York, NY, USA, 1976; Volume 1, p. 116.

94. Champion, A.R.; Krueger, W.H.; Hartman, H.S.; Dhingra, A.K. Fiber FP reinforced metal matrix composites. In Proceedings of the Second International Conference on Composites Materials, Toronto, ON, Canada, 16-20 April 1978; TMS-AIME: New York, NY, USA, 1978; p. 883.

95. Kimura, Y.; Mishima, Y.; Umekawa, S.; Suzuki, T. Compatibility between carbon fiber and binary aluminum alloys. J. Mater. Sci. 1984, 19, 3107-3114. [CrossRef]

96. Su, H.; Gao, W.; Zhang, H.; Liu, H.; Lu, J.; Lu, Z. Optimization of stirring parameters through numerical simulation to prepare aluminum matrix composite by the stir casting process. J. Manuf. Sci. Eng. 2010, 132, 061007. [CrossRef]

97. Naher, S.; Brabazon, D.; Looney, L. Computational and experimental analysis of particulate distribution during Al-SiC MMC fabrication. Compos. Part A Appl. Sci. Manuf. 2007, 38, 719-729. [CrossRef]

98. Sadowski, T.; de Borst, R. (Eds.) Lecture Notes on Composite Materials: Current Topics and Achievements; Springer Science \& Business Media: Berlin/Heidelberg, Germany, 2008; Volume 154.

99. Evans, A.; San Marchi, C.; Mortensen, A. Metal matrix composites. In Metal Matrix Composites in Industry; Springer: Boston, MA, USA, 2003; pp. 9-38.

100. Matthews, F.L.; Rawlings, R.D. Composite Materials: Engineering and Science; Elsevier: Amsterdam, The Netherlands, 1999.

101. Almadhoni, K.; Khan, S. Review of effective parameters of stir casting process on metallurgical properties of ceramics particulate Al composites. IOSR J. Mech. Civ. Eng. 2015, 12, 22-40.

102. Langford, J.C.; Perras, M.A. Obtaining reliable estimates of intact tensile strength. In Proceedings of the 48th US Rock Mechanics/Geomechanics Symposium, Minneapolis, MN, USA, 1-4 June 2014; OnePetro: Richardson, TX, USA, 2014. 